\title{
Development of a Superior Somaclone of Rose-scented Geranium and a Protocol for Inducing Variants
}

\author{
Ritika Gupta, S. Banerjee, G.R. Mallavarapu, S. Sharma, \\ S.P.S. Khanuja, A.K. Shasany, and Sushil Kumar ${ }^{1}$ \\ Central Institute of Medicinal and Aromatic Plants, P.O. CIMAP, Lucknow- \\ 226015, India
}

Additional index words. Pelargonium graveolens, somaclonal variation, calliclones, essential oil yield and quality

\begin{abstract}
An efficient protocol has been established for generating somaclones in the Indian rose-scented geranium Pelargonium graveolens cv. Bipuli, which yields Reunion Island-type essential oil. Murashige and Skoog's (MS) medium supplemented with 4.5 $\mathrm{mg} \cdot \mathrm{L}^{-1} \mathrm{BA}$ and $1.0 \mathrm{mg} \cdot \mathrm{L}^{-1} \mathrm{NAA}$ was found optimal for induction of callus from leaf explants. Callus regenerated shoots when transferred to MS medium with $2.5 \mathrm{mg} \cdot \mathrm{L}^{-1} \mathrm{BA}$ and $0.1 \mathrm{mg} \cdot \mathrm{L}^{-1} \mathrm{NAA}$. The regeneration percentage as well as number of shoots per $\mathrm{cm}^{2}$ of callus was greatly improved by addition of ADS at a concentration of $3.0 \mathrm{mg} \cdot \mathrm{L}^{-1}$. Regenerated shoots rooted within 20 days following transfer to half-strength MS medium with $0.1 \mathrm{mg} \cdot \mathrm{L}^{-1} \mathrm{NAA}$. Plantlets were acclimatized under glasshouse conditions with $80 \%$ to $85 \%$ survival. Randomly selected 30 individual calliclones were subjected to field trial with wild-type parent in randomized block design, replicated three times with $90 \%$ survival for two successive years. Characterization of these calliclones for essential oil yield and quality traits demonstrated induction of variability in all the characteristics examined in negative and positive directions in comparison with the wild-type parent. This screening led to the identification of somaclone B22, which out-yielded the wild-type parent as well as the rest of the somaclones. The quality of the essential oil of $\mathrm{B} 22$ was similar to that of the parent. Chemical names used: $N^{6}$-benzyladenine (BA); naphthalene acetic acid (NAA); adenine di-sulphate (ADS).
\end{abstract}

Geranium oil is one of the most important essential oils, extensively used for imparting a pronounced and lasting roselike odor in high-grade perfumes and soaps. Many cultivars of rose-scented geranium Pelargonium graveolens are grown in various countries for distillation of geranium oil (Gulati, 1960; Lawrence, 1984). This crop is vegetatively propagated, and the annual production of oil is estimated to be in the range of $\approx 300$ tonnes (Qinghua, 1993). The commercial value of geranium oil depends on its quality, which is mainly determined by the total rhodinol content and ratio of citronellol and geraniol. The highest quality geranium oil, which is obtained from the Bourbon cultivar of Reunion Island origin, contains almost equal amounts of geraniol and citronellol (Rajeswara Rao et al., 1995). The cultivars of Chinese and Egyptian origins produce relatively inferior quality oils. To meet the growing international re-

Received for publication 13 Dec. 2000. Accepted for publication 13 June 2001. Grateful thanks are due to S. Ramesh, S.A. Hasan, and Shalini Rai for the GC analysis of oil and preparation of the manuscript, and to the Dept. of Biotechnology, Government of India, for partial financial support.

${ }^{1}$ To whom reprint requests should be addressed: Prof. Sushil Kumar, National Center for Plant Genome Research (NCPGR), JNU Campus, Post Box 10531, New Delhi-110067, India. E-mail address: sushil2000_01@yahoo.co.in quirements for high-quality geranium oil, there is a need to produce more oil of the Reunion Island type.

Although several kinds of agroclimates in India appear suitable for geranium cultivation, only 5 tonnes of geranium oil are presently produced in India per year. Geranium cultivation is confined to the Nilgiri and Palini hills of southern India (Rajeswara Rao et al., 1969). The cultivation of geranium in this area dates to the early 18 th century, when Portuguese priests introduced a small number of accessions of $P$. graveolens. Germplasm brought from Reunion Island and Algeria is now grown in India. The sensitivity of these genetic resources to several diseases and pests, especially white ant infestations and to water stagnation in the rainy season, does not permit economic cropping of geranium in the Indian plains. The development of suitable cultivars to meet these challenges is hindered by the narrow genetic base and sterility in the available accessions.

The parasexual genetic engineering and tissue culture-based somaclonal variation induction techniques offer possibilities for genetic improvement in the vegetatively propagated rose-scented geranium. Somaclonal variation generated through regeneration of plants from callus culture has already proved to be an effective and practical means to create increased variability relatively rapidly and without the deleterious genetic changes that get counterselected through the process of whole-plant regeneration (Dunbar, 1997; Evans, 1989; Larkin and Scowcroft, 1981; Veilleux and Johnson, 1998).

Somaclonal variation techniques find their greatest applications for crop improvement only when a series of independently derived somaclones are judiciously evaluated under relatively stringent field conditions, and the desired variants are selected on the basis of improved economic characteristics. Somaclonal variation technique has been successfully employed for the improvement of ornamental geraniums $P$. zonale and $P$. hortorum (Abo-el-Nil and Hilderbrandt, 1973; Bottino and Hammerschlag, 1981; Chen and Galston, 1965, 1967; Dunbar and Stephens, 1989; Hakkaart and Hartel, 1979; Horst et al., 1976; Pillai and Hilderbrandt, 1968, 1969; Qureshi and Saxena, 1992), and scented geranium Pelargonium graveolens (Brown and Charlwood, 1986; Lakshmana Rao, 1994; Satyakala et al., 1995; Saxena et al., 2000; Skirvin and Janick, 1976a). One of these studies led to the development of a somaclonal variant, called 'Velvet rose' as a new cultivar (Skirvin and Janick, 1976b). The present work describes a method for somaclonal variation induction, and the spectrum of variation observed in the somaclones recovered from selection of a highly productive somaclone of the Bourbon-type rose-scented geranium cv. Bipuli.

\section{Material and Methods}

Explant source. The Bourbon-type rosescented geranium cultivar Bipuli, which survives the northern Indian climatic conditions, was the source of explant for the present study. Healthy, potted 5- to 6-month-old glasshousegrown plants obtained from 'Bipuli' stem cuttings served as the explant source. The explants, namely young leaves, were washed under running tapwater for $30 \mathrm{~min}$ and then surface-sterilized for $2-3 \mathrm{~min}$ in $2.5 \%(\mathrm{v} / \mathrm{v})$ savlon solution (a germicide containing chlorhexidine gluconate $0.3 \% \mathrm{v} / \mathrm{v}$ and cetrimide $0.6 \% \mathrm{w} / \mathrm{v})$, followed by $0.1 \%(\mathrm{w} / \mathrm{v})$ $\mathrm{HgCl}_{2}$ solution with constant agitation, and finally rinsed 3-5 times with sterile doubledistilled water.

Culture medium and conditions. Murashige and Skoog's (Murashige and Skoog, 1962) medium, containing 3\% sucrose and 100 $\mathrm{mg} \cdot \mathrm{L}^{-1}$ myoinositol, was used as the basal medium. The MS medium was supplemented with NAA $\left(0.1-1.0 \mathrm{mg} \cdot \mathrm{L}^{-1}\right)$ in combination with BA $\left(2.5-5.0 \mathrm{mg} \cdot \mathrm{L}^{-1}\right)$. The $\mathrm{pH}$ of the medium was adjusted to 5.8 before gelling with $0.8 \%$ agar (Hi-media Laboratories Private Ltd., Bombay, India) and autoclaved under $104 \mathrm{kPa}$ at $121^{\circ} \mathrm{C}$ for $15 \mathrm{~min}$. Sterilized entire young leaves were placed horizontally with abaxial side down on the media surface in a 100-mL Erlenmeyer flask. Each treatment consisted of 10 explants; there were three replications. Cultures were maintained at $25 \pm$ $1{ }^{\circ} \mathrm{C}, 60 \%$ relative humidity, and $16-\mathrm{h}$ photoperiod at $35 \mu \mathrm{mol} \cdot \mathrm{m}^{-2} \cdot \mathrm{s}^{-1}$ flux density. Observations were recorded at 1-week intervals. After 4 weeks of culture, the percentage of 
callus induction from leaf segments, growth performance of the calli, percent callus explants forming shoots, and average number of shoots per $\mathrm{cm}^{2}$ of callus were recorded and have been summarized in Tables 1 and 2 , respectively.

After induction, the calli were subcultured on MS medium supplemented with reduced NAA $\left(0.1-0.5 \mathrm{mg} \cdot \mathrm{L}^{-1}\right)$, BA $\left(2.5-3.5 \mathrm{mg} \cdot \mathrm{L}^{-1}\right)$, and ADS (1.0-5.0 $\left.\mathrm{mg} \cdot \mathrm{L}^{-1}\right)$ for inducing shoot regeneration.

Rhizogenesis. For rooting in vitro, regenerated shoots $(2-3 \mathrm{~cm}$ in length) with four to five fully expanded leaves were excised and transferred to four media combinations differing in basic salts strength as well as in auxin concentration (Table 3).

Acclimatization and transfer to soil. Wellrooted plantlets with eight to 10 fully expanded leaves were removed from culture medium and the roots washed gently under running tapwater to remove the traces of medium. The plantlets were kept in a glasshouse at $26 \pm 1{ }^{\circ} \mathrm{C}$ and $80 \%$ relative humidity for a week. The plantlets were transplanted into pots containing coarse sand for 2 weeks, and then moved to pots containing 1 sand : 1 soil : 1 farmyard manure. Fifty calliclones were established in a glasshouse, 30 of which were selected randomly for the field trial. These were multiplied via stem cuttings. The plants obtained were transferred to field trials during the third week of October. The calliclones were arranged in randomized blocks, replicated nine times. Cuttings of all 30 clones and a control parent were maintained under glasshouse conditions during the monsoon (JulySeptember) and then were subjected to a second year of field trial starting the third week of October. Data were recorded for plant height, canopy size, herb yield, number of branches, number of leaves, leaf : stem ratio, leaf area, oil content, and oil yield for all the somaclones during both years. All data were subjected to the test of significance using the Critical Difference (CD) test at 5\% and 1\% levels of significance (Cochran and Cox, 1957).

Extraction of oil and gas chromatography. Six months after planting, all the plants were evaluated for oil content and oil composition. Oil content was determined by distilling herb samples in Clevenger's apparatus (Clevenger, 1928). Contents of 11 major constituents of oil were determined by gas chromatography (GC). $\mathrm{GC}$ and GC-MS analyses of the oils were performed as described earlier (Kulkarni et al., 1998). Data on oil content and oil composition were subjected to the test of significance using the $\mathrm{CD}$ test at $5 \%$ and $1 \%$ levels of significance.

Molecular analysis of hybrids. DNA was isolated from young leaves $(1 \mathrm{~g})$ of mature plants following the reported protocol (Khanuja et al., 1999) and was digested with EcoRI restriction endonucleases. A set of 20 decanucleotide primers (M/S Bangalore Genie, India) were used for PCR amplification. Polymerase chain reaction (PCR) was carried out in $25 \mu \mathrm{L}$ reaction volume, containing 20 $40 \mathrm{ng}$ of plant genomic DNA, $125 \mu \mathrm{M}$ of

Table 1. Effects of phytohormones on induction, establishment, and growth of callus cultures arising from leaf explants in rose-scented geranium (Pelargonium graveolens cv. Bipuli).

\begin{tabular}{|c|c|c|c|}
\hline $\begin{array}{l}\mathrm{NAA} / \mathrm{BA}^{\mathrm{z}} \\
\left(\mathrm{mg} \cdot \mathrm{L}^{-1}\right)\end{array}$ & $\begin{array}{l}\text { \% Callus } \\
\text { induction }\end{array}$ & $\begin{array}{c}\text { Growth } \\
\text { performance }\end{array}$ & Nature/color of callus \\
\hline $1.0 / 2.5$ & 42 & ++ & Friable to compact/creamish to light green \\
\hline $1.0 / 3.5$ & 54 & + & Compact/green \\
\hline $1.0 / 4.5$ & 67 & +++ & Very friable/yellow \\
\hline
\end{tabular}

Table 2. Effects of concentrations and combinations of growth regulators on shoot regeneration from calli in rose-scented geranium (Pelargonium graveolens $\mathrm{cv}$. Bipuli).

\begin{tabular}{lccccc}
\hline $\begin{array}{l}\text { Sl. } \\
\text { no. }\end{array}$ & \multicolumn{2}{c}{ Phytohormone concn $\left(\mathrm{mg} \cdot \mathrm{L}^{-1}\right)$} & $\begin{array}{c}\text { \% Callus segments } \\
\text { that produced shoots }\end{array}$ & $\begin{array}{c}\text { No. of shoots } \\
\text { produced/cm }{ }^{2} \text { of callus }\end{array}$ \\
\hline 1 & 0.5 & 2.5 & 0 & $39.0 \pm 5.0$ & $8.6 \pm 0.5$ \\
2 & 0.5 & 3.5 & 0 & $34.6 \pm 7.2$ & $5.9 \pm 0.9$ \\
3 & 0.1 & 2.5 & 0 & $61.2 \pm 8.2$ & $12.2 \pm 1.2$ \\
4 & 0.1 & 3.5 & 0 & $56.2 \pm 7.4$ & $10.9 \pm 3.6$ \\
5 & 0.1 & 2.5 & 1.0 & $82.1 \pm 9.2$ & $28.2 \pm 2.8$ \\
6 & 0.1 & 2.5 & 3.0 & $94.6 \pm 8.7^{\mathrm{w}}$ & $40.3 \pm 5.2$ \\
7 & 0.1 & 2.5 & 5.0 & $92.8 \pm 8.2$ & $45.2 \pm 6.4$ \\
\hline
\end{tabular}

${ }^{\mathrm{2}} \mathrm{NAA}=1$-naphthalene acetic acid.

${ }^{\mathrm{y}} \mathrm{BA}=6$-benzyl amino purine.

${ }^{x} \mathrm{ADS}=$ adenine di-sulphate

${ }^{\text {w }}$ Regeneration response on this medium was significantly superior to that on corresponding medium without ADS, as revealed by $t$ test with $95 \%$ level of confidence.

Table 3. Effects of MS salts strength, auxin type, and concentration on the rooting of the in vitro-raised shoots of rose-scented geranium (Pelargonium graveolens $\mathrm{cv}$. Bipuli).

\begin{tabular}{lccccc}
\hline $\begin{array}{l}\text { Sl. } \\
\text { no. }\end{array}$ & $\begin{array}{c}\text { MS } \\
\text { strength }\end{array}$ & $\begin{array}{c}\text { Auxin } \\
\left(\mathrm{mg} \cdot \mathrm{L}^{-1}\right)\end{array}$ & $\begin{array}{c}\text { \% of shoots } \\
\text { that rooted }\end{array}$ & $\begin{array}{c}\text { No. of roots } \\
\text { formed/shoot }\end{array}$ & $\begin{array}{c}\text { Mean root } \\
\text { length }(\mathrm{cm})^{\mathrm{y}}\end{array}$ \\
\hline 1 & $1 / 2$ & $0.1 \mathrm{NAA}^{\mathrm{x}}$ & 96 & $9.7 \pm 0.3^{\mathrm{w}}$ & $2.0 \pm 0.4^{\mathrm{w}}$ \\
2 & $1 / 2$ & $0.5 \mathrm{NAA}^{\mathrm{N}}$ & 60 & $3.2 \pm 0.2$ & $0.6 \pm 0.2$ \\
3 & $1 / 2$ & $0.5 \mathrm{IBA}^{\mathrm{v}}$ & 80 & $1.5 \pm 0.2$ & $0.3 \pm 0.1$ \\
4 & $1 / 2$ & $1.0 \mathrm{IBA}^{2}$ & 40 & $3.0 \pm 0.2$ & $0.6 \pm 0.4$ \\
\hline
\end{tabular}

${ }^{\mathrm{z}} \mathrm{MS}=$ Murashige and Skoog.

y Observations were recorded at $20 \mathrm{~d}$ from transfer of shoots on to the rooting medium. ${ }^{\mathrm{N}} \mathrm{NA}=1$-naphthalene acetic acid

${ }^{\text {w}}$ Rooting response on this medium was significantly superior to that on the other media, as revealed by $t$ test, with $95 \%$ level of confidence.

${ }^{\mathrm{IBA}}=$ indole butyric acid.

$\mathrm{MgCl}_{2}, 100 \mu \mathrm{m}$ of each dNTP, $5 \mathrm{p}$ м of primer, and 0.2 units of Taq DNA polymerase. Amplification was carried out in DNA Engine PTC 200 (MJ Research Inc., Waltham, Mass.) thermal cycler programmed for 45 cycles of $1 \mathrm{~min}$ at $94{ }^{\circ} \mathrm{C}, 1 \mathrm{~min}$ at $36^{\circ} \mathrm{C}$, and $2 \mathrm{~min}$ at $72{ }^{\circ} \mathrm{C}$. The amplification cycle was concluded with final extension at $72{ }^{\circ} \mathrm{C}$ for $5 \mathrm{~min}$. Amplification products were electrophoresed in $1.2 \%$ $(\mathrm{w} / \mathrm{v})$ agarose gel, visualized by ethidium bromide $\left(0.5 \mu \mathrm{g} \cdot \mathrm{mL}^{-1}\right)$ staining. The pictures of the gel were scanned for the presence of polymorphic fragments, which were scored for the presence $(+)$ or absence $(-)$ of bands. The data so generated were used for calculating the index of genetic similarity using Nei and Li's (1979) matching coefficient method. The similarity indices were calculated by the formula: $2 \times$ (number of similar bands between the two accessions/total number of bands in the two accessions). These values were then used to generate a dendrogram with unweighted pair group method using arithmetic average (UPGMA) cluster analysis (Table 5; Fig. 3).

\section{Results and Discussion}

The present study demonstrated that the leaf explant of rose-scented geranium $\mathrm{cv}$. Bipuli was highly responsive toward in vitro callusing, as has already been reported earlier in other species (Dunbar and Stephens, 1989) and a different cultivar of $P$. graveolens (Lakshmana Rao, 1994). All three combinations of BA and NAA tested for induction of callusing were found to be effective (Table 1); however, the media containing $4.5 \mathrm{mg} \cdot \mathrm{L}^{-1} \mathrm{BA}$ and $1.0 \mathrm{mg} \cdot \mathrm{L}^{-1} \mathrm{NAA}$ showed best callusing response where $67 \%$ of the leaf explants formed callus within $12-15 \mathrm{~d}$ of culture initiation. The resultant callus was highly friable and yellow in color. Lower amounts of compact and light green to green callus was formed on the other two media. The present findings are similar to the earlier report on $P$. hortorum (Pillai and Hilderbrandt, 1969) and that on $P$. graveolens cv. Hemanti (Saxena et al., 2000) in terms of the suitability of low auxin and high cytokinin concentrations for callus induction. 
Table 4. Variation in the expression of essential oil yield and quality related traits among 27 somaclones and their wild-type parent in rose-scented geranium (Pelargonium graveolens cv. Bipuli).

\begin{tabular}{|c|c|c|c|c|c|c|c|c|c|c|}
\hline $\begin{array}{l}\text { S1 } \\
\text { no. }\end{array}$ & Character & \multicolumn{2}{|c|}{$\begin{array}{l}\text { Measurement } \\
\text { over } 27 \text { clones }\end{array}$} & \multicolumn{5}{|c|}{$\begin{array}{l}\text { Expression among } 5 \text { of the } 27 \text { somaclones } \\
\text { selected for their superior performance }\end{array}$} & $\begin{array}{c}\text { Control } \\
\text { parent }\end{array}$ & $\begin{array}{c}\text { Critical } \\
\text { difference } \\
(\mathrm{CD} \text { at } 5 \%)\end{array}$ \\
\hline a) & \multicolumn{10}{|c|}{ Oil yield related ${ }^{w}$} \\
\hline 2 & Canopy $\left(\mathrm{m}^{2}\right)$ & $0.6-1.6$ & $1.2 \pm 0.1$ & $1.6 \pm 0.2$ & $1.0 \pm 0.73$ & $1.3 \pm 0.04$ & $1.4 \pm 0.06$ & $1.6 \pm 0.03$ & $0.81 \pm 0.08$ & 0.2 \\
\hline 3 & Herb yield $\left(\mathrm{kg} / \mathrm{pl}^{\mathrm{v}}\right)$ & $2.1-9.1$ & $6.2 \pm 0.4$ & $9.1 \pm 0.2$ & $7.5 \pm 0.1$ & $5.7 \pm 0.2$ & $8.7 \pm 0.1$ & $8.9 \pm 0.3$ & $4.3 \pm 0.06$ & 0.7 \\
\hline 4 & No. of $\mathrm{br} / \mathrm{pl}^{\mathrm{u}}$ & $21-43$ & $32 \pm 1$ & $43 \pm 3$ & $29 \pm 4$ & $36 \pm 5$ & $40 \pm 6$ & $40 \pm 2$ & $25 \pm 2$ & 1.0 \\
\hline 5 & No. of $1 \mathrm{vs} / \mathrm{pl}^{\mathrm{t}}$ & $740-2933$ & $824 \pm 112$ & $2690 \pm 143$ & $2366 \pm 88$ & $1800 \pm 244$ & $1966 \pm 115$ & $2366 \pm 256$ & $1437 \pm 100$ & 593 \\
\hline 8 & Oil yield/pl (g/pls $)$ & $4.5-36.1$ & $1.9 \pm 2.2$ & $36.1 \pm 1.6$ & $29.2 \pm 1.4$ & $20.2 \pm 1.0$ & $35.2 \pm 1.04$ & $27.2 \pm 0.22$ & $10.5 \pm 0.03$ & 10.0 \\
\hline 9 & Oil content (\%) & $0.27-0.45$ & $0.38 \pm 0.1$ & $0.45 \pm 0.1$ & $0.43 \pm 0.02$ & $0.44 \pm 0.05$ & $0.40 \pm 0.05$ & $0.34 \pm 0.03$ & $0.29 \pm 0.01$ & 0.11 \\
\hline b) & \multicolumn{10}{|c|}{ Oil quality related ${ }^{w}(\%)$} \\
\hline 1 & Geraniol & $13.7-36.4$ & $22.6 \pm 0.6$ & $21.0 \pm 1.3$ & $24.8 \pm 0.4$ & $26.3 \pm 2.2$ & $21.8 \pm 0.9$ & $23.4 \pm 1.3$ & $21.8 \pm 3.3$ & 6.5 \\
\hline 2 & Citronellol & $21.6-39.3$ & $27.2 \pm 1.0$ & $31.5 \pm 0.6$ & $29.7 \pm 0.3$ & $28.0 \pm 2.5$ & $33.7 \pm 1.2$ & $27.9 \pm 2.3$ & $34.5 \pm 3.4$ & 4.3 \\
\hline 3 & Linalool & $2.4-8.5$ & $5.8 \pm 0.2$ & $6.3 \pm 2.6$ & $5.1 \pm 1.2$ & $4.8 \pm 0.6$ & $6.4 \pm 0.4$ & $6.3 \pm 1.9$ & $4.3 \pm 1.6$ & 2.7 \\
\hline 9. & Geranyl formate & $2.1-3.8$ & $2.7 \pm 0.1$ & $2.5 \pm 0.1$ & $2.7 \pm 0.2$ & $3.3 \pm 0.2$ & $2.2 \pm 0.1$ & $2.9 \pm 0.3$ & $2.1 \pm 0.2$ & 0.5 \\
\hline 10. & 10-epi-g-eudesmol & $4.4-7.1$ & $2.7 \pm 0.1$ & $5.8 \pm 0.7$ & $6.9 \pm 0.2$ & $6.1 \pm 0.3$ & $6.3 \pm 0.1$ & $5.9 \pm 0.2$ & $5.7 \pm 0.3$ & 0.5 \\
\hline
\end{tabular}

${ }^{2}$ Clones selected for high herb and oil yields.

${ }^{y}$ Clones selected for high oil yield.

${ }^{\mathrm{x}}$ Clones selected for high herb yield.

"Observations were recorded on the somaclones and their parent replicated grown in a replicated field trial during 1998-99, 1999-2000 cropping seasons.

${ }^{\mathrm{k}} \mathrm{kg} / \mathrm{plant}$.

"Number of branches/plant.

'Number of leaves/plant.

${ }^{\mathrm{s}}$ Grams/plant.

In the course of the present study, shoot regeneration response could be recorded through repeated subculturing and prolonged growth of the calli on the MS medium containing $3.5 \mathrm{mg} \cdot \mathrm{L}^{-1} \mathrm{BA}$ and $1.0 \mathrm{mg} \cdot \mathrm{L}^{-1} \mathrm{NAA}$. However, the resultant regenerants were malformed and vitrified in nature. Reduction in the level of auxin led to some degree of improvement in the morphology of the regenerants, as well as percent response and number of shoots per $\mathrm{cm}^{2}$ of callus. A maximum of $61.2 \% \pm 8.2 \%$ shoot regeneration was recorded on medium containing $2.5 \mathrm{mg} \cdot \mathrm{L}^{-1} \mathrm{BA}$ and $0.1 \mathrm{mg} \cdot \mathrm{L}^{-1} \mathrm{NAA}$ within $30 \mathrm{~d}$ of culture; each $\mathrm{cm}^{2}$ of callus produced $12.2 \pm 1.2$ shoots (Table 2 ). The addition of ADS from 1.0 to $5.0 \mathrm{mg} \cdot \mathrm{L}^{-1}$ concentrations along with $2.5 \mathrm{mg} \cdot \mathrm{L}^{-1} \mathrm{BA}$ and 0.1 $\mathrm{mg} \cdot \mathrm{L}^{-1} \mathrm{NAA}$ greatly improved the regeneration response up to $95 \%$; and on average $>40$ shoots appeared on $\mathrm{cm}^{2}$ of callus. While the shoots formed with 1.0 to $3.0 \mathrm{mg} \cdot \mathrm{L}^{-1}$ supplementation of ADS to $\mathrm{MS}+2.5 \mathrm{mg} \cdot \mathrm{L}^{-1} \mathrm{BAP}+$ $0.1 \mathrm{mg} \cdot \mathrm{L}^{-1} \mathrm{NAA}$ were healthy, those produced on the same medium supplemented with 5.0 $\mathrm{mg} \cdot \mathrm{L}^{-1}$ ADS were abnormal and vitrified. Stimulatory effect of ADS in multiple-shoot induction from callus culture of the Egyptian oil-type $P$. graveolens cv. Algerian has been reported earlier (Lakshmana Rao, 1994).

Different cytokinins at different levels proved effective for in vitro regeneration of shoots from calli of different geranium species and cultivars. BAP in combination with some auxin has proved effective for optimum regeneration response in certain floricultural geranium species (Qureshi and Saxena, 1992) and scented geranium species (Brown and
Charlwood, 1986; Saxena et al., 2000) In certain other reports, either kinetin, zeatin, or $2 \mathrm{iP}$ was found effective for optimum level of regeneration response from callus cultures (Bottino and Hammerschlag, 1981; Dunbar and Stephens, 1989; Lakshmana Rao, 1994; Pillai and Hilderbrandt, 1969). The in vitroregenerated shoots of the present study elongated further when subcultured on hormonefree solid MS medium and attained a size of $1.5-2.5 \mathrm{~cm}$ in $10 \mathrm{~d}$.

Best rhizogenesis results, both in terms of percent response and number of roots per shoot, were obtained in one-half strength MS medium supplemented $0.1 \mathrm{mg} \cdot \mathrm{L}^{-1} \mathrm{NAA}$ (Table 3). Comparable results were obtained with one-half strength MS medium supplemented with $0.5 \mathrm{mg} \cdot \mathrm{L}^{-1} \mathrm{IBA}$, but the number of roots formed and root length were significantly lower (Table 3). Moreover, the plantlet growth on the former medium was better with sturdier internodes suitable for in vivo acclimatization. The present finding differs from earlier reports (Lakshmana Rao, 1994; Satyakala et al., 1995; Saxena et al., 2000) where instead of NAA, IBA was found to be more effective for optimum rhizogenesis response.

Plantlets with expanded leaves and welldeveloped roots were transferred to a glasshouse for hardening. The plantlets were initially transferred to pots containing coarse sand and maintained under glasshouse conditions where $80 \%$ to $85 \%$ survival was noted. Subsequently, the healthy-looking plantlets were transferred to pots containing 1 garden soil : 1 coarse sand : 1 farmyard manure. Among the 50 individual calliclones estab- lished in the glasshouse, 30 healthy-appearing, randomly selected individual clones along with their control parent were transferred to field conditions during Oct. 1998, where only 27 clones survived. All these clones were field-planted in randomized block design (replicated three times, with three plants per plot), were allowed to grow for 6 months, and then harvested for determining the yield and quality of oil. The field trial was again repeated in the winter-summer cropping season of 19992000. The averaged results of the two consecutive field trials are presented in Table 4.

It will be seen from Table 4 that in all the characteristics except height, somaclones harbored variation in both directions, i.e., more than as well as less than the value of the level of expression of characteristics observed in the control parent strain. Among the somaclones there was more than a 4-fold difference in herb yield and an 8-fold difference in oil yield. There were large differences (1.5$4 \times$ ) among somaclones for characteristics such as canopy size, number of branches per plant, number of leaves per plant, leaf : stem ratio,

Table 5. Average similarity indices between 'Bipuli' parent cultivar accession and its selected five calliclones.

\begin{tabular}{lcccccc}
\hline \hline Accession & Bipuli & B3 & B6 & B13 & B22 & B20 \\
\hline Bipuli & 1.00 & & & & & \\
B3 & 0.72 & 1.00 & & & & \\
B6 & 0.55 & 0.75 & 1.00 & & & \\
B13 & 0.73 & 0.73 & 0.67 & 1.00 & & \\
B22 & 0.64 & 0.89 & 0.79 & 0.75 & 1.00 & \\
B20 & 0.80 & 0.98 & 0.78 & 0.75 & 0.92 & 1.00
\end{tabular}




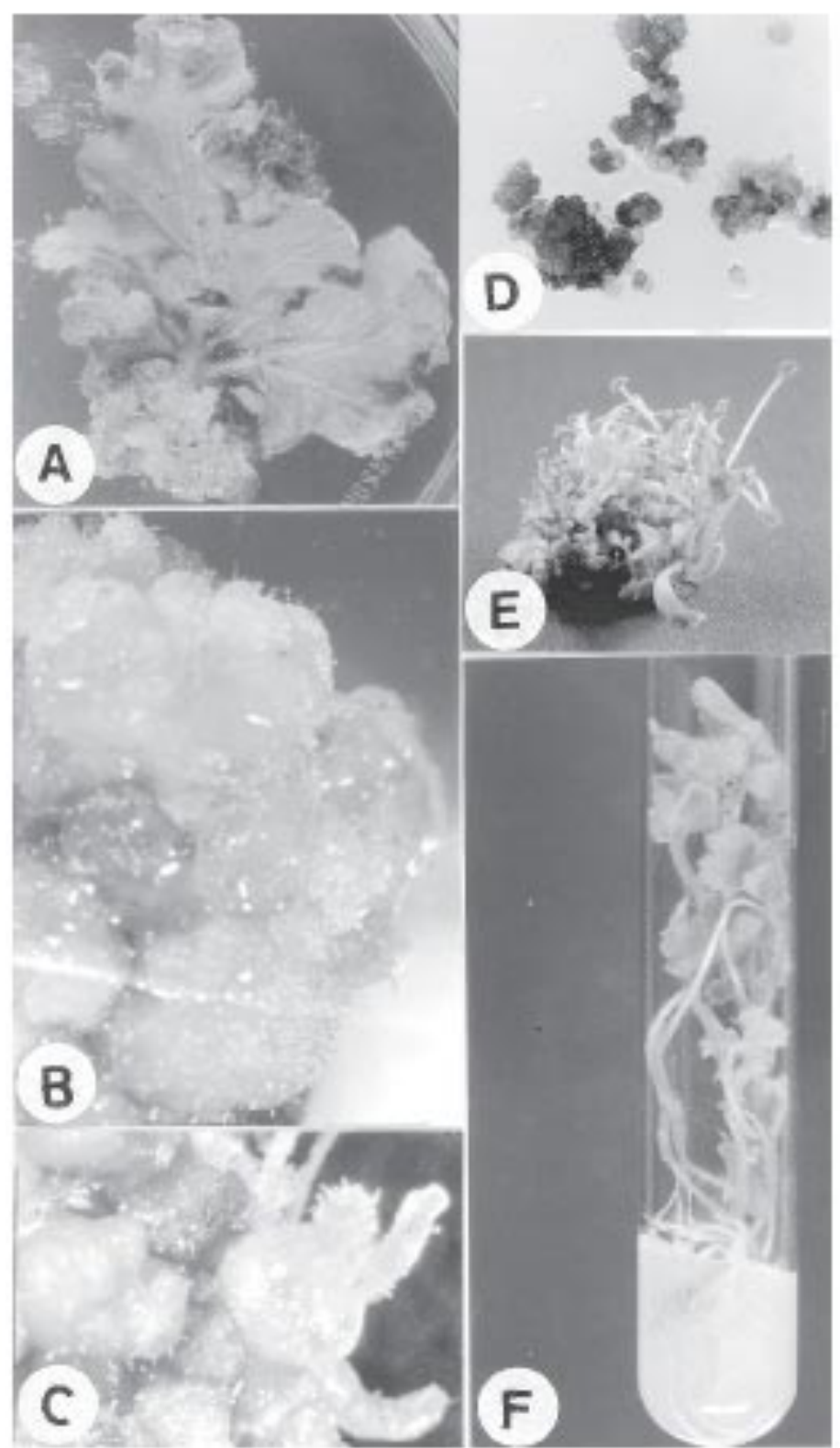

Fig. 1. Rezeneration of soemackonal variantis) in the lndian cultivar Bipuli. roesscenled geranium Pelargonixm granwoiews- ( $\mathbf{\Lambda}$ ) inductioe of callus from leat explant: (B) compact green callus underzoing regeneration, (C-E) regenerz. tion of plantlets from callus; $\{\mathbf{F}$ ) in vitro rhixogenesis and complete plantlet formation in vitro.
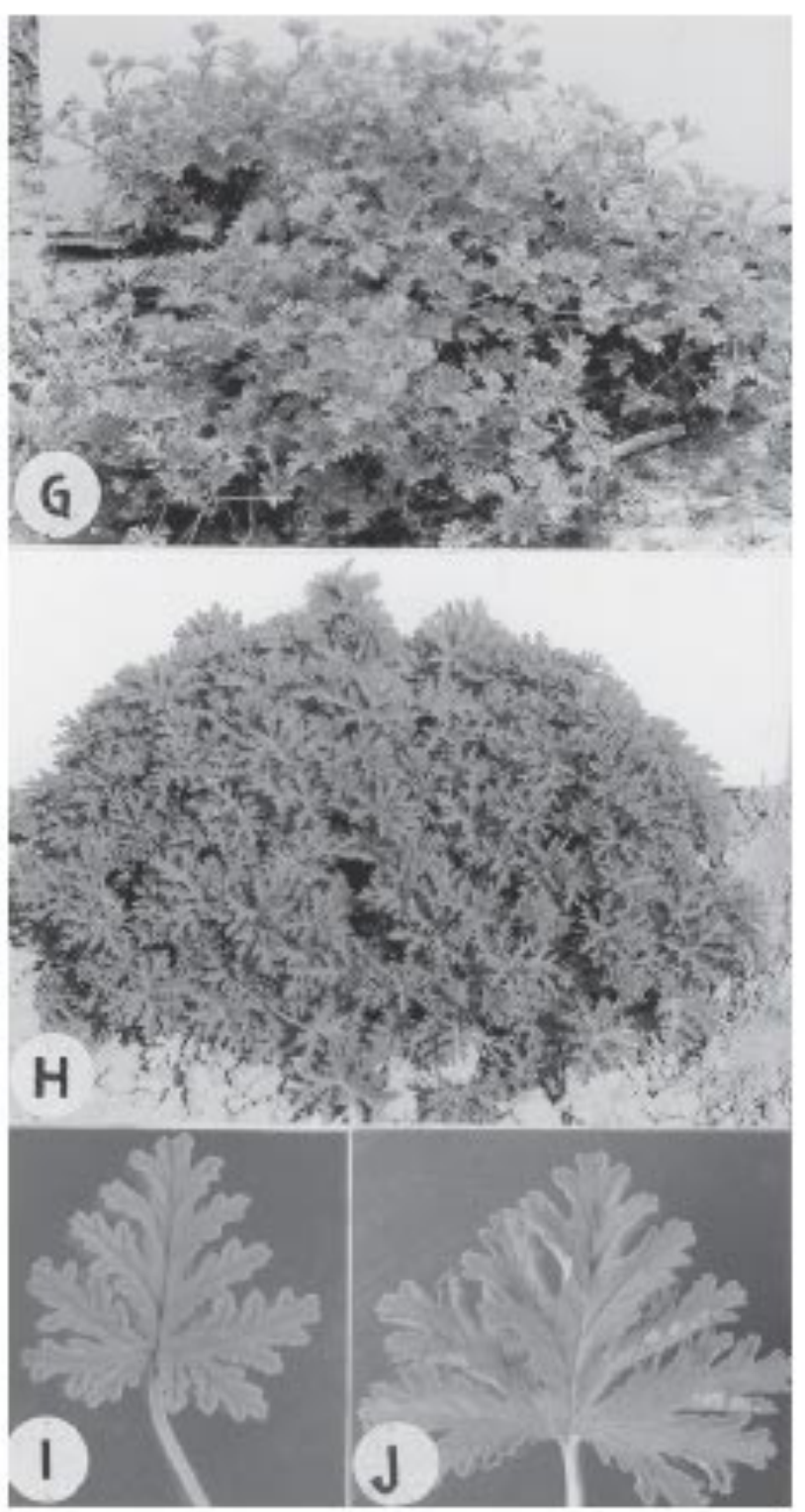

Fig. 2. Moqphologies of the field-gronen plants of two accessions of the rase-scented geranium Pelarganixm graveolens: (G) 24-week-old field-zrown plarx of 'Bipuli'; and (H) somaclone B22 developed from 'Bipuli': typical leaves of (I) 'Bipuli' and (J) B22. leaf area, and ofl content. The mean values for all the esential oil yield-related characteristics studjed were higher for somaclones than for the corresponding values for the parentsl strain. Table 5 compares the expression of ot yield-telated characteristics of the selected calliclones B3, B6, B22, B13, B17, and the 'Bipuli' parent cultivar. The berb yield of calliclones was mote than 2-fold and the ox content 1.2- to 1.5-fold of 'Bipuli'.

The RAPD snalysis of the DNAs of these clones and the 'Bipuli' parent using 20 decanucleotide primers was cartied out to ascertain genetic differences between the somaclones and similarity between them and the parent (Fig. 3). In Table 5, which compares the similarity indices of the calliclone getotypes and control parent, calliclones of "Bipuli" demonstrated homologies varying from $55 \%$ to $80 \% \%$ with the parent cultivar and $67 \%$ to $98 \%$ homology among themselves. The preseace of genetic differences between the calliclones and the parent proved that the calliclones were somaclonsl mutsints. Since the expression of characters in them was tepested in the two seasons of evaluation, it could be concluded that geentypic changes responsible for phenotypic differences between them and the parents were stably inherited.

Somsclone B22 wasselected is which both berb snd oil yields were significantly higher than those of other somaclones studied. The B22 plants were tall, highly beanched, and camed a very large number of big leaves, such that a very large canopy was formed. The oil contentin the shoot of $\mathrm{B} 22$ was $0.45 \%$, highest among all the somaclones inducod and the parent. Presumably, all these characteristics contributed towards highest berband oil yields given by this clone in comparison with sll the geentypes compsred in the study. In cour titerature search, thus far no rose-scented getanium cultivars have been reported to contain essential oil in their hetbage to the same extent as that present in clone B22 (Ram et al., 1995). Table 4 also presents the variation is profiles of essential oils of the wild type, and 27 somsclones developed in the study in terms of a set of 10 terpenoids that are important detetminants of the quality of geranium oil. On average, the induced clones bad somewhat lower citronellol. cis- and trans-tose oxides. citronelly1 and getanyl formates, mentbone. isomentboes, and 10 epa- $\gamma$-eudesmol contents in their essential cols as compared with essential oil of the wild type. The quality of the 


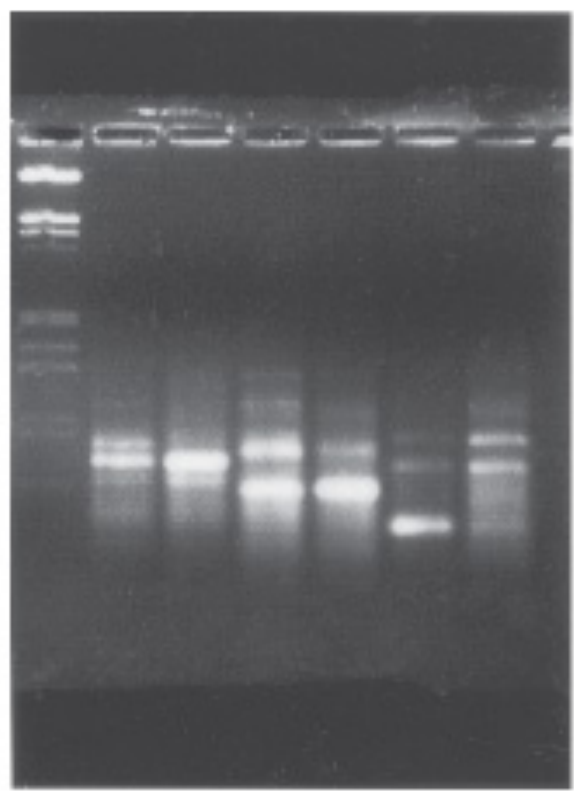

Fig. 3. DNA protiles of selected somaxclonal variants and the parent 'Bipuli' of rose-scented geranium Pelargonixm gravwolews: [left to right] lane 1 has molecular weight nsorkers; lane 2 is 'Bipuli' control; and lanes 3-7 are 'Bipuli' callickones B3, B6, B13, B22, and B1?

esential oil of B22 was, however, on par with that of the wild-type control parent.

We conclude that: 1) the somaclonal variation induction techaigue can be successfully used to widen the genetic variability in essential ot yield in the rose-scented, reproductively sterile, geranium genotype; 2) as far as the author knows, somackoe B22 is the most productive genotype among the available cultivars in rose-scented geranium for producing essential oil.

\section{Literature Cited}

Abo-el-NiL M.M. and A.C. Hildertrand. 1973. Origin of androgenetic callus and haploid geranium plants. Can. J. Bot. 51:2107-2109.

Bottino, P. and F. Hanvmerschlag. 1981. Effect of plant age on callus growth, plant regencration and anther culture of geranium. J. Aner. Soc. Hort. Sci. 106:114-116

Brown. J.T. and B.V. Churlwood. $1980 \mathrm{~b}$. The con. trol of callus formation and differentiation in scenced pelargoeniums. J.Plant Physiol. 123:409. 413.

Chen. H.R. and A.W. Galston. 1965. Growth and development of Pelargonixm pith cells in vitro, I. Indection of cell division. Physiol. Plant. 18: $454-460$

Chen. H.R. and A.W. Galsten. 1967. Growth and development of Pelarganiam pith cells in vitro II. Initiation and orgarized developunere. Physiol. Plant. 20:533-539.

Clevenger JF. 1928. Apparatus for the determination of volatile oil. J. Amer. Fharm. Assoc. 17:346.

Cochran W.G. and G.M. Cox 1957. Experinsental designes. 2nd ed. Wiley. New Yoek.

Evans, Duvid A. 1989. Somaclonal variation-Genetic basis and breeding applicationes. Trends Genet 5 $504-50$.

Dunbar, K.B. and C.T. Stephens. 1989. Shoot regeneration of hybrid seed geranium (Pelargawive xhortarve) and regal geranium (Pelargawive xdomesticxm) from prinwry callus cultures. Plant Cell Tiss. Ory. Cult. 19:13-21.

Dunbsr R.R. 1997. Tissue culture induced variztions and crop improvement, p. 201-240. In: Advasces inagrcesomy, vol.5\& Academic Press, New York.

Gulati. B.C 1960. Cultivation of geranium. Ind. Oil Soap J. 286(2):35-43.

Hakkaart, F.A. and G. Hartel. 1979. Virus eradication fromsome PelargonixM zowale cultivars by meristematip cultures. Netherlands J. Plant Path. $85.39+46$.

Horst, R.K., S.H. Snich, H.T. Horst, and W.A. Oplevee. 1976 . Virus, diseases of omanventals. Acta Hort. 5\%.131-142.

Kulkarni, R.N., G.R. Mallavarapu, K. Baskaran, S. Ramesh, and S. Kamar. 1998. Composition of essential oils of two isomenthone nich variants of geranium (Pelargowiumspp., . Flav. and Frag. J. 13:389-392.

Lakshmama Ras, P.V. 1994. in vitro regeneration of scented-leaved geranium Pelarganivm grambalews. Plant Sci. 98:193-198.

L.arkin, PJ. and W.R.Scoucroft. 1981. Somaclonal variations - A novel source of variability from cell culoures forplant improvement. Theor. Appl. Genet 60-197-214.

Lawrence, B.M. 1984. Progress in essential oils.
Perf. and Flav, 9:987-995.

Murashige, T. and F. Skoog. 1962. A revised medium for rapid arowth and bioassays with iobacco tissue cultures. Physiol. Plant. 15:473497 .

Nei. M. and W.H. Li. 1979. Marhematical nodel for studying genetic variation in terms of restrictioe endoeuclease. Proc. Nat. Acad. Sci. U.S.A. 74:5267-5273.

Pillai, S.K. and A.C. Hildertrandt 1968. Geranium plants differentiaked is vitro from stem tip and callus cultures. Plant Dis. Rep. 52:52-58.

Pillai, S.K. and A.C. Hildertrandt. 1969. Induced differentiation of zeranium plants from undifferentiated callus in virno. Aner. J. Bot 56:5258.

Qinghuz,Z 1993. China's perfunwery indestry picks up. Perf. and Flav. 18: 47-48.

Qureshi, J.A. and P.K. Saxenz. 1992. Adventitioux shoot induction and somatic enbryogenesis with intact seedlings of several hybrid seed geranium varieties(Pelarzonium $\times$ hontonam Bailey). Plant Cell Rep. 11:443-448.

Rajeswara Kao, B.R., EVS.P. Rao, and M.R. Narayana. 1989. Kose geranium: An eccoomical crop in the south lndian Plains. Ind. Hort. 36:14-17.

Ram, M., M.M. Gupes, A.A. Naqvi, and S. Kunser. 1995. Commercially viable arrual crop of geranium in northern Indian plains. Current Kes. of Medicinal and Aromatic Plants (now J. Medici. nal and Aromatic Plant Sci.) 17:17-20.

Satyakala G., M. Muralidhar Rao, and G. Laxmi Suta 1995. I vitro micropropazation of scented geranium (Pelanganiam groverolens L Her. Ex. Ait.: Syn P. rosenm wild). Curr. Sci. 6817 $\times 762$ 765.

Saxena. G., S. Bznerjee. L. Rahman. G.R. Mallaxarapu, S. Shama, and S. Kumar. 2000 An efficient in vitre procedure for micropropagation and generation of somaclones of rase-scented Pelarganiam. Plant Sci. 155: 133 140.

Skirvin R.M. and J. Janick. 1976a. Tissue culture. Induced variation in scented Pelargenixo sp. J. Am. Soc. Hort. Sci. 101:281-290.

Skirvin R_M and J. Janick. 1976b. "Velvet rose" Pelurgowive: A scented geranium. HortScience 11:61-62.

Veilleux, R.E and A.A.T. Johnson. 1998. Sousclonal variations: Molecular analyxis, tranoformation inceraction and utilization, p. 229-268. Inc J. Janick (ed.). Plant Broeding Rev. vol. 16. Wiley, New York. 